\title{
Opportunities and challenges for integrating dairy cattle into farms with certified organic pineapple production as perceived by smallholder farmers in Central Uganda
}

\author{
S. Nalubwama • F. Kabi • M. Vaarst • M. Kiggundu • \\ G. Smolders
}

Received: 10 July 2017 / Accepted: 14 March 2018

(C) Springer Science+Business Media B.V., part of Springer Nature 2018

\begin{abstract}
A study was conducted in 2013 to assess opportunities and challenges of integrating dairy cattle into organic pineapple production in Uganda. Thirty organic pineapple farmers were interviewed using a semistructured questionnaire. The main dairy cattle management systems were tethering $(73 \%)$ and zero grazing (27\%). Average landholding was $1.74 \pm 1.06$ and 3.75 \pm 2.70 ha for zero grazing and tethering systems, respectively. All farms were diversified with various livestock such as cattle, goats, sheep, pigs, and chickens and crops including pineapples, maize, coffee, bananas, beans, sweet potatoes, and cassava. The level of integration of dairy cattle into pineapple production depended on the distance of crop fields from the livestock enterprises. More farms $(83 \%)$ with pineapple fields closer $(<$ $0.5 \mathrm{~km}$ ) to the homesteads were able to use cattle manure as fertilizer compared to homesteads $(50 \%)$ with more distant fields $(>0.5 \mathrm{~km})$. The distance to the homestead
\end{abstract}

S. Nalubwama $(\bowtie)$

Department of Livestock and Industrial Resources, Makerere University, P.O. Box 7062, Kampala, Uganda

e-mail: drnalubwama@gmail.com

F. Kabi · M. Kiggundu

Department of Agricultural Production, Makerere University,

P.O. Box 7062, Kampala, Uganda

M. Vaarst

Department of Animal Science, Aarhus University, P.O. Box 50,

DK-8830 Tjele, Denmark

G. Smolders

OrgANIMprove, Karveel 13-03, 8231 AT Lelystad, the

Netherlands did not influence $30 \%$ of the farmers who used crop residues for feeding dairy cattle. Farmers perceived cattle diseases and feed scarcity to be the major challenges in dairy farming. The sources of risk on the farms were perceived to be erratic rainfall, limited knowledge, and market for organic products. Majority of farmers (77\%) expressed willingness to convert to organic dairy production. Availability of markets for organic dairy products (36\%) and reduction of external input use (26\%) were the main reasons for farmers' willingness to convert. Integrating dairy cattle with pineapple production is an opportunity for closed nutrient cycles and income diversification. However, knowledge, access to inputs, and organized markets are needed as incentive for conversion to organic dairy production.

Keywords Certified · Conversion · Crop-livestock integration · Organic $\cdot$ Perception $\cdot$ Smallholder farms

\section{Introduction}

Integration of livestock into organic pineapple production is essential in closing nutrient cycles as required by organic principles and standards. In integrated croplivestock systems, the emphasis must be put on biodiversity which promotes efficient nutrient recycling at low cost rather than on the nutrient importation from surrounding areas (McDermott et al. 2010). Pauselli (2009) projected that organic production will continue to grow globally since it offers effective means of satisfying consumer demands for healthy and safe food as well as 
contributing to non-economic factors such as environmental protection. While some countries in Europe and America practice certified organic livestock production, in Uganda, it is still non-existent (Willer and Lernoud 2015; Nalubwama et al. 2011). Livestock mainly exists in diversified smallholder farms but are not fully integrated.

Organic pineapple production is becoming very important for smallholder farmers in Uganda due to the prevailing local, regional, and international organic markets (Nalubwama et al. 2016). It contributes about 55\% to organic farmers' household incomes (Kwikiriza et al. 2016). Currently, there are no large-scale producers of organic pineapples in Uganda. Production is exclusively by smallholder contract farmers organized in groups and registered under certified organic export companies which meet the cost of certification (Kiggundu 2015). The common variety of pineapples grown is smooth cayenne although other varieties like "rough cayenne" and "victoria" are also produced by some farmers. Smallholder organic pineapple farmers employ various organic practices which include using of manure and coffee husks as both fertilizer and mulch and intercropping pineapples with maize, beans, bananas, and fruit trees (Nalubwama et al. 2014).

Apart from producing fresh pineapple fruits, some smallholder farmers are involved in agro-processing of produce to products such as sun-dried pineapple slices, wines, juices, and pulp which fetch a higher market price (Chongtham et al. 2010). Whereas agroprocessing is advantageous, it generates large quantities of by-products/wastes, which require proper management and disposal to avoid pollution of the surrounding ecosystem. But for farms where ruminants are kept, pineapple wastes are potential animal feed resource (Negesse et al. 2009). While the traditional knowledge and experience perfectly favor smallholder farmers to apply integration, in practice, few adopt the innovation under organic systems due to limited knowledge and technologies in organic animal husbandry, lack of alternative approach to controlling diseases and pests, lack of direct financial benefits, and limited access to assets and other inputs (Nalubwama et al. 2014; IFAD 2005). Moreover, in a highly improved crop-livestock system, sustainable production can be guaranteed where residues, wastes, and by-products of each component serve as a resource for the other (IFAD 2005).

Due to increased demand for organic livestock products, there are opportunities for smallholder farmers to convert to organic livestock production and benefit from related income diversification that will accrue from increased market share. It is relevant to consider such market-orientated development for sustainable livestock production targeting high-value markets for increased income and employment among smallholder farmers (ICROFS 2010). Attributes and perceptions related to product availability, its appearance, and taste were reported to be critical in enhancing regularity of organic food purchases in Uganda (Anecho 2015). However, in a study by Nalubwama et al. (2016), smallholder dairy farmers in Uganda produced only small quantities of milk mainly for home consumption with a small surplus for sale, consequently, not benefiting from market opportunities. Conversely, it was earlier noted by Kavoi et al. (2013) that non-price factors such as environmental sustainability that accrue from integration might be even more relevant to dairy farmers than price factors for development. This is because, sometimes, smallholder dairy farmers valued non-marketable products of their animals, especially for those whose livestock enterprises typically provided livelihood under variable conditions (Moll et al. 2007).

Nonetheless, there are other benefits of having the whole farming systems in balance according to organic principles such as mutual and sustainable exploitation of nutrients through nutrient recycling. According to Karki et al. (2012), the factors influencing farmers' decisions on conversion to organic production included environmental awareness, bright market prospects, observable economic benefits, and health consciousness. Similarly, Martine-Garcia et al. (2015) reported that the decision to change management practices or adopt technology among dairy smallholder farmers was strongly connected to immediate benefits. Therefore, the objective of this study was to assess opportunities, challenges, and risk factors of integrating dairy cattle into certified organic pineapple production as perceived by smallholder organic pineapple farmers and their willingness to convert the dairy production on their farms to certified organic.

\section{Materials and methods}

\section{Study area}

The study was conducted in Luwero and Kayunga districts in Central Uganda. Both districts are principle areas for certified organic pineapple production (FIT 2007). Kayunga is situated about $74 \mathrm{~km}$ east of Kampala by road at an altitude of about $1100 \mathrm{~m}$ above sea level. 
The district lies at $0.9860^{\circ} \mathrm{N}$ and $32.8536^{\circ} \mathrm{E}$. Annual temperature typically varies from 16 to $30^{\circ} \mathrm{C}\left(21^{\circ} \mathrm{C}\right)$. There is significant seasonal variation in humidity, March to December (68\%), in May (96\%), and January (59\%). Luwero is located about $75 \mathrm{~km}$ north of Kampala by road at an altitude of about $1250 \mathrm{~m}$ above sea level. The district lies at $0.8271^{\circ} \mathrm{N}$ and $32.6277^{\circ} \mathrm{E}$. Annual temperature typically varies from 15 to $31{ }^{\circ} \mathrm{C}$. The district also experiences significant seasonal variation in humidity with March to December (62\%), May (92\%), and January (52\%). Farmers in the two districts practice rain-fed agriculture. The rainfall pattern is bimodal with the rainy seasons stretching from March to May and October to November. The average annual rainfall (2013-2016) was 1287 and $1263 \mathrm{~mm}$ in Luwero and Kayunga, respectively (calculated on basis of data obtained from https://www.worldweatheronline. com/luwero-weather-averages/luwero/ug.aspx and https://www.worldweatheronline.com/kayungaweather-averages/kayunga/ug.aspx, respectively).

\section{Data collection}

A study was conducted in May-July 2013 to gather data from mixed smallholder certified organic pineapple farmers. The farmers were purposefully selected from a larger sample in the previous study based on certified organic pineapple production and presence of at least one dairy cow (Nalubwama et al. 2014). Eleven farmers with zero grazing system from a previous study were included, and simple random sampling was used to select the remaining 19 farmers from a group of 61 farmers with tethering system. A semi-structured questionnaire was used to collect data. The questionnaire was divided into three sections: (1) farmer characteristics, (2) farm characteristics, and (3) farmer experiences, perceptions, and knowledge. The sub-sections included demographics, land size and use, herd structure, and management practices. In addition, the questionnaire included open-ended questions to get insight into how integration of cattle with organic pineapple production is effected and farmers' perceptions of opportunities and challenges in dairy production and their motivation for converting to certified organic dairy production. Farmers were requested to rate the sources of risk on their farms associated with integration of livestock into pineapple production and the factors affecting uptake of organic livestock farming as "unimportant," "important," or "very important."
Data analysis

Data collected were analyzed using SPSS 16.0 statistical package (SPSS Inc., Chicago, Illinois, USA) for descriptive statistics. Test for significance of categorical data was performed using chi-square test, while for continuous variables, the significance was measured using $t$ test. Effects were considered significant at $P<0.05$. Farmers' perceptions were ranked according to their average using the Likert average scale values.

\section{Results}

Household demographics and management systems

Household demographics, hectarage, and resource use as influenced by management systems are presented in Table 1 . The main dairy cattle management systems were tethering $(73 \%)$ and zero grazing $(27 \%)$. Of the households practicing tethering or zero razing system, 95 and $73 \%$ were male farmers, respectively. In the tethering system, cattle were restrained using a rope secured on a pole around which the cattle grazed. Cattle were grazed in areas designated as grassland, in some farms natural pastures were the dominant source of feeds, and in others they were grazed along roadsides. In the zero grazing system, cattle were confined and fed under the "cut and carry" feeding system. In this system, the grass was partly harvested from own established fodder gardens, grasslands, and partly harvested from other areas outside the farm including roadsides. The years farmers spent at school, number of years farmers were engaged in dairy farming, and number of lactating cows did not vary $(P>0.05)$ with the management system. Total hectarage of land and the area under crops were larger at the farms with tethering system $(P<0.05)$ than with a zero grazing system. Irrespective of the farming system, majority of the households mainly used family labor (67\%) for farm activities. Similarly, irrespective of the management system, majority of the households (70\%) had farming as their major source of income and livelihood.

\section{Land allocation to crops and livestock}

Hectarage, crop diversity, and number of total livestock units (TLU) kept by the certified organic pineapple farmers in relation to management system and the 
distance of pineapple fields from homesteads are shown in Table 2. On farms with tethering system, $47 \%$ of the farmers had pineapple fields more than $0.5 \mathrm{~km}$ away from the homestead, while under zero grazing system they were only $27 \%$. Moreover, all farms were diversified with several animal species such as cattle, goats, sheep, pigs, and chickens and various cash crops and food crops including pineapples, maize, coffee, bananas, beans, sweet potatoes, and cassava. The land allocated to certified organic pineapple production in the tethering system was twice that allocated to the pineapple production under the zero grazing system irrespective of the distance of the pineapple fields from the homesteads. Farms with tethering system and pineapple fields on a distance more than $0.5 \mathrm{~km}$ away had lower hectarage for pineapple but with higher acreage for crops other than pineapples compared with the tethering farms with pineapple close to the homestead, while under zero grazing system the reverse was true. Similarly, there was more crop diversity on farms with pineapple fields situated more than $0.5 \mathrm{~km}$ away from homesteads under tethering system, while under zero grazing system more crop diversity was observed on farms with pineapple fields located less than $0.5 \mathrm{~km}$ away from the homesteads. Fewer livestock units were kept on farms with pineapple fields located less than $0.5 \mathrm{~km}$ away from the homestead in both management systems.

Integration of livestock into organic crop production

The recycling of by-products from livestock (manure) and crops (crop residues) as influenced by the distance of certified organic pineapple fields from homesteads is presented in Table 3. More farms $(83 \%)$ with pineapple fields closer $(<0.5 \mathrm{~km})$ to the homesteads used cattle manure on crops compared to those homesteads (50\%) with more distant pineapple fields $(>0.5 \mathrm{~km})$. The percentage of farmers who used crop residues for feeding dairy cattle was $28 \%$ for farms with pineapple fields located less than $0.5 \mathrm{~km}$ away from the homestead and $33 \%$ for farms with pineapple fields situated more than $0.5 \mathrm{~km}$ away from homesteads. Generation of income from cattle manure as a soil amendment for organic crop production was unpopular among the farmers irrespective of the distance of the pineapple fields from the homesteads. However, use of crop residues as a source of income was more popular for organic pineapple fields, which were within a distance of less than $0.5 \mathrm{~km}$. Consequently, majority of farmers with organic pineapple fields at a distance more than $0.5 \mathrm{~km}$ neither used the cattle manure for crop production nor for income generation.

\section{Perceptions of sources of farm risks by farmers}

The sources of farm risks rated by farmers in tethering and zero grazing systems are presented in Fig. 1. Weather, management, farmers' knowledge, production diseases, endemic diseases, markets for products, farm inputs, and policy issues were the sources of farm risks rated by the farmers. Weather variability, farmers' knowledge, and markets where rated by 70,47 , and $40 \%$ of farmers as very important sources of risk, respectively. Conversely, fewer farmers rated production diseases, farm inputs, and policy issues as very important sources of risk by proportions of 20,17 , and $3 \%$, respectively. Half of the farmers who rated weather as very important perceived production diseases and farm inputs as unimportant sources of risk for their farm. Almost two thirds of the farmers perceived production diseases as an unimportant source of risk and half of the farmers perceived endemic diseases as an unimportant source of risk for their farm. The risk for endemic diseases was perceived more important for farmers in tethering system compared to zero grazing system. Farmers who perceived weather changes, lack of knowledge, risk of production diseases, and limited markets as very important kept more animals than farmers that perceived those factors unimportant. For the risk of farm management and farm inputs, it was just the opposite: farmers who perceived this unimportant had more animals.

Willingness and motivation to convert to organic dairy production

Reasons for converting to certified organic dairy production mentioned by $77 \%$ of all farmers participating in the survey, who expressed willingness to convert, are presented in Fig. 2. Among the farmers who expressed willingness to convert, more were zero grazing farmers $(81 \%)$ compared to those who were tethering $(74 \%)$. There was no significant difference $(P>0.05)$ between farmers in these two management systems in terms of age, gender, education, and number of years as organic pineapple farmers.

The farmers who indicated that they would convert to certified organic dairy production were asked reasons for their definite conversion. Among these, 34\% indicated markets for organic animal products as their main 
Table 1 Average age of interviewed farmers, education, and land size in the tethering and zero grazing systems

\begin{tabular}{|c|c|c|c|c|c|c|}
\hline \multirow[t]{3}{*}{ Variable } & \multicolumn{4}{|c|}{ Management systems } & \multirow[t]{3}{*}{ SEM } & \multirow[t]{3}{*}{$P$ value } \\
\hline & \multicolumn{2}{|c|}{ Tethering $(n=19)$} & \multicolumn{2}{|c|}{ Zero grazing $(n=11)$} & & \\
\hline & Mean \pm std & Min-max & Mean \pm std & Min-max & & \\
\hline Age of respondents & $45.6 \pm 10.9$ & $32-77$ & $51.8 \pm 9.4$ & $35-68$ & 3.942 & 0.128 \\
\hline Years of education & $7.5 \pm 2.4$ & $4-14$ & $8.9 \pm 2.9$ & $6-13$ & 0.975 & 0.167 \\
\hline Years in dairy farming & $12.3 \pm 10.7$ & $2-50$ & $8.6 \pm 5.1$ & $2-19$ & 3.452 & 0.302 \\
\hline Numbers of lactating cows & $2.3 \pm 3.2$ & $1-15$ & $1.2 \pm 0.4$ & $1-2$ & 0.969 & 0.274 \\
\hline Total land size (ha) & $3.75 \pm 2.7$ & $0.8-10.7$ & $41.74 \pm 1.1$ & $0.6-4.5$ & 2.111 & 0.026 \\
\hline Ha of land under crops & $2.52 \pm 1.5$ & $0.8-6.1$ & $1.41 \pm 0.9$ & $0.6-3.6$ & 1.197 & 0.027 \\
\hline Ha of land under grass & $1.24 \pm 2.1$ & $0-8.1$ & $0.33 \pm 0.4$ & $0-1.0$ & 1.556 & 0.162 \\
\hline
\end{tabular}

motivation. This group of farmers had the largest farms and most grassland and had the longest experience in dairying. The farmers that indicated reduced external inputs $(26 \%)$ as their main motivation had the largest herds and smaller area of grass and were the intensive dairy farmers (zero grazing). Majority of the farmers who were not willing to convert to organic animal husbandry mentioned lack of knowledge on organic animal husbandry as the main limitation. Expensive inputs and costs of conversion were also mentioned as reasons for their unwillingness to convert to organic dairy production.

Perception of problems currently faced by farmers in dairy production

Problems currently faced in dairy production by certified organic pineapple farmers are presented in
Table 4. By segregating farmers who were willing to convert to organic dairy production from those who were not, it became clear that the problems in dairy production were perceived differently. Farmers listed on average 1.8 problems with a wide variability. Cattle diseases and pests were reported as the major problem faced by the farmers whether willing or not willing to convert to organic dairy production. Farmers that would definitely convert listed problems with animal health (diseases and pests, expensive drugs, limited herbal medicine, and expensive veterinary costs), limited markets, scarcity and high cost of hired labor, and lack of land. Farmers that would probably/not convert only listed problems with health of the animals (diseases and pest and lack of veterinary service), lack of feed and high cost and scarcity of hired labor.

Table 2 Land size, crop diversity, and number of cattle kept by certified organic pineapple farmers in relation to management system and the distance of pineapple fields from homesteads

\begin{tabular}{|c|c|c|c|c|}
\hline \multirow[t]{3}{*}{ Variable } & \multicolumn{4}{|c|}{ Management systems } \\
\hline & \multicolumn{2}{|l|}{ Tethering } & \multicolumn{2}{|c|}{ Zero grazing } \\
\hline & $<0.5 \mathrm{~km}$ & $>0.5 \mathrm{~km}$ & $<0.5 \mathrm{~km}$ & $>0.5 \mathrm{~km}$ \\
\hline Number of farms & 10 & 9 & 8 & 3 \\
\hline Total land size (hectares) & 3.58 & 3.95 & 2.05 & 0.92 \\
\hline Pineapple land size (hectares) & 1.0 & 0.72 & 0.50 & 0.37 \\
\hline Other crop land size (hectares) & 1.4 & 1.91 & 1.14 & 0.42 \\
\hline $\begin{array}{l}\text { Number of other crop types } \\
\text { other than pineapples (diversity) }\end{array}$ & 4.2 & 4.6 & 3.5 & 3.3 \\
\hline *Number of cattle (TLU) & 2.3 & 5.8 & 2.0 & 2.9 \\
\hline
\end{tabular}

*Number of dairy cattle comprising cows, heifers, male and female calves, bulls, and steers calculated as total livestock units (TLU) 
Table 3 Integration of dairy cattle into crops and crops into dairy cattle as influenced by the distance of certified organic pineapple fields from homesteads

\begin{tabular}{|c|c|c|c|c|c|c|c|}
\hline \multicolumn{4}{|c|}{ Integration of dairy cattle into organic crops } & \multicolumn{4}{|c|}{ Integration of organic crops into dairy cattle } \\
\hline Distance & $<.5 \mathrm{~km}(n=18)$ & $>.5 \mathrm{~km}(n=12)$ & Total $(n=30)$ & & $<.5 \mathrm{~km}(n=18)$ & $>.5 \mathrm{~km}(n=12)$ & Total $(n=30)$ \\
\hline Manure use & $15(83)$ & $6(50)$ & $21(70)$ & Crop residues & $5(28)$ & $4(33)$ & $9(30)$ \\
\hline Income generation & $1(6)$ & 0 & $1(3)$ & Income & $4(22)$ & $1(8)$ & $5(17)$ \\
\hline Not integrated & $2(11)$ & $6(50)$ & $8(27)$ & Not integrated & $9(50)$ & $7(58)$ & $16(53)$ \\
\hline
\end{tabular}

Numbers in parenthesis represent percent

Strategies to overcome the problems in dairy production

A list of strategies by the farmers responding to the question: "what coping strategy do you use?" is presented in Table 5. Animal treatment was mentioned most as coping strategy in dairy production irrespective of whether farmers are willing or not willing to convert to organic livestock production.
Other coping strategies mentioned by farmers willing to convert to organic dairy production included improving on management practices (22\%), feeding (13\%), and hire of additional land for extensive grazing/fodder production (13\%). Farmers not willing to convert mentioned feeding (43\%), use of family/causal labor (29\%), and seeking expert advice $(14 \%)$ as coping strategies.

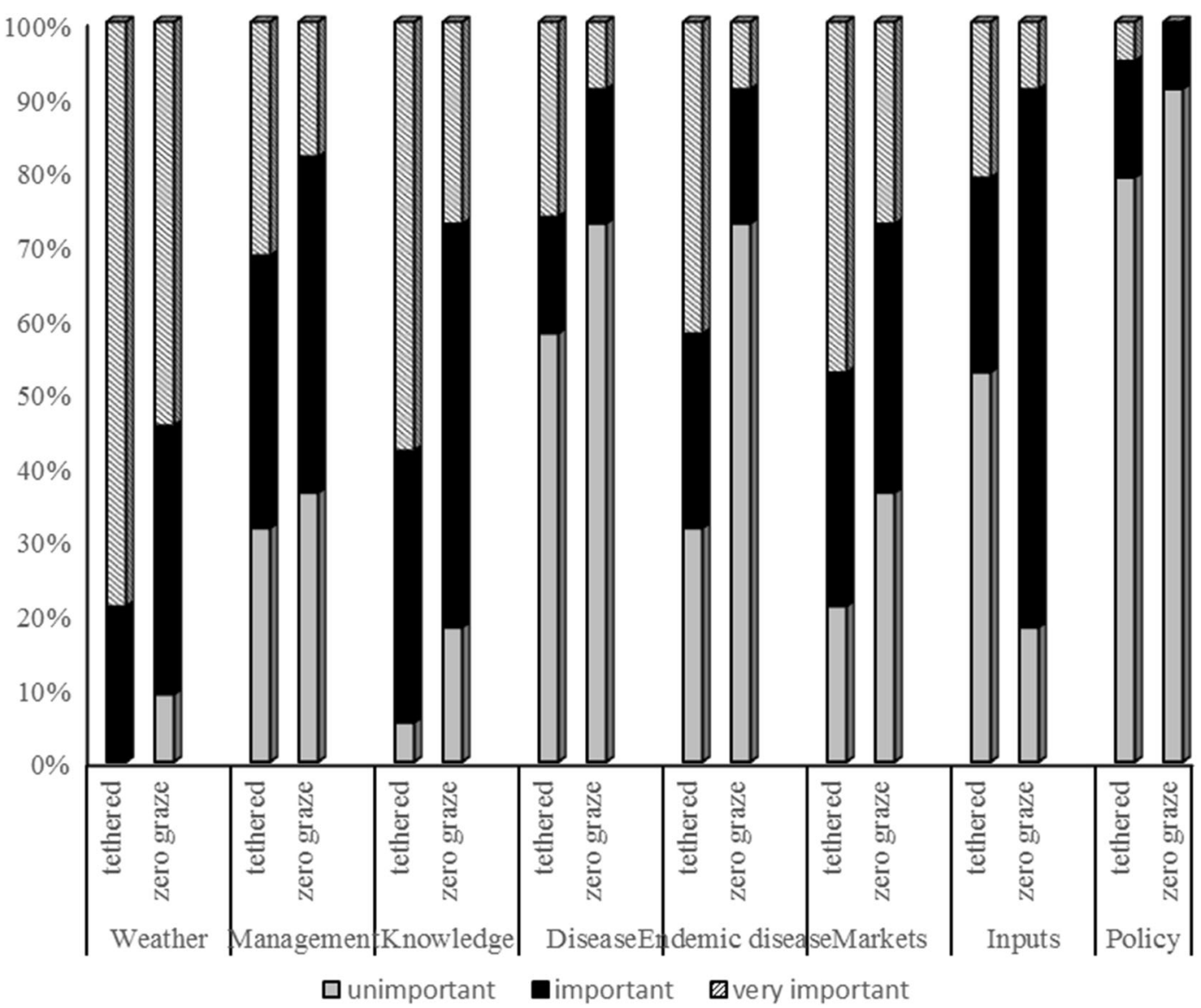

Fig. 1 Sources of risks in tethering and zero-grazing farms as rated by organic farmers. Farmers were required to rate each of the 8 options as unimportant, important, or very important 
Fig. 2 Reasons for converting to certified organic dairy production listed by the 23 farmers who expressed willingness to convert

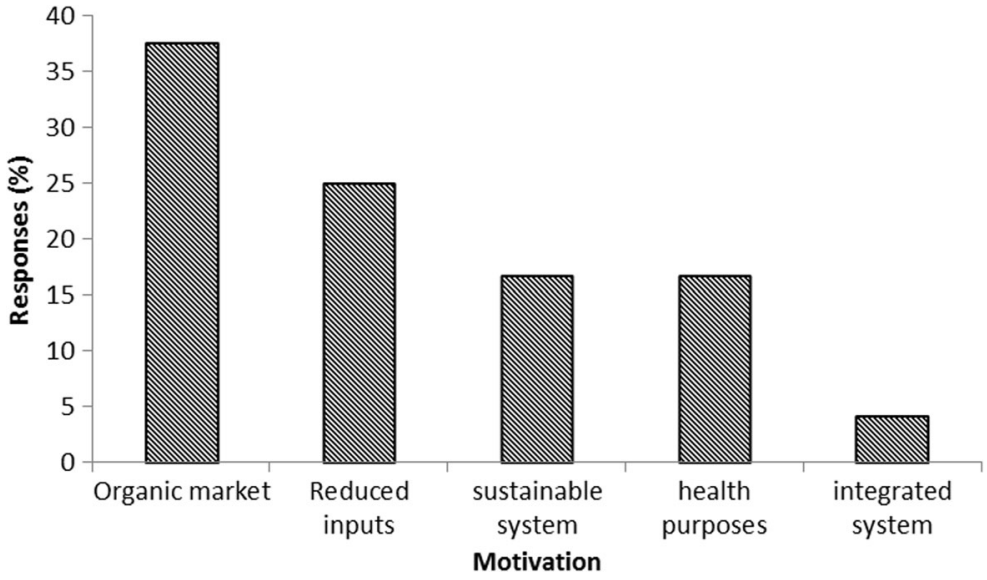

Rating of important factors for uptake of organic livestock production by farmers

Rating of factors considered important in the uptake of organic dairy production by farmers is presented in Fig. 3. Six factors including availability of capital, source of organic inputs, information/knowledge about organic husbandry, knowing who to go to with question or complaint (presence of peers), information on market for organic products, and years of practicing/conversion to organic farming were rated according to how farmers perceived them as important bottle necks to conversion to organic dairy farming. Among these, knowledge,

Table 4 Problems encountered in dairy production as mentioned by the organic farmers

\begin{tabular}{lll}
\hline *Perceived problems & $\begin{array}{l}\text { Response to conversion } \\
(\% \text { of respondents })\end{array}$ \\
\cline { 2 - 3 } & $\begin{array}{l}\text { Definitely } \\
(n=23)\end{array}$ & $\begin{array}{l}\text { Probably/not } \\
(n=7)\end{array}$ \\
\hline $\begin{array}{ll}\text { Diseases and pests } \\
\text { Limited markets for milk }\end{array}$ & 39 & 57 \\
$\begin{array}{l}\text { Limited feeds during dry } \\
\text { season }\end{array}$ & 26 & 0 \\
$\begin{array}{l}\text { Scarcity and high cost } \\
\text { of hired labor }\end{array}$ & 22 & 29 \\
$\begin{array}{l}\text { Expensive inputs } \\
\quad \text { feeds/drugs) }\end{array}$ & 22 & 29 \\
$\begin{array}{l}\text { Limited land } \\
\text { Limited herbal remedies } \\
\text { Fluctuating weather }\end{array} \quad 17$ & 0 \\
$\quad$ conditions & 9 & 0 \\
$\begin{array}{l}\text { Expensive veterinary costs } \\
\text { Limited veterinary services }\end{array}$ & 4 & 0 \\
\hline
\end{tabular}

source of organic inputs, and capital for investment were rated as the most important factors by farmers willing to convert to organic dairy production. However, those not definite on conversion rated knowledge, source of organic inputs, and market information as very important factors. Both groups perceived knowledge/information as very important but did not perceive peers as the best way to get informed.

\section{Discussion}

Most of the household heads in organic pineapple farms under study were literate having obtained the minimum level of education. Earlier studies reported

Table 5 List of strategies by the farmers responding to the question: what coping strategy do you use (regarding overcoming the problems in dairy production)?

\begin{tabular}{lll}
\hline Variable & \multicolumn{2}{l}{$\begin{array}{l}\text { Response to conversion (\% } \\
\text { of respondents })\end{array}$} \\
\cline { 2 - 3 } & $\begin{array}{l}\text { Definitely } \\
(n=23)\end{array}$ & $\begin{array}{l}\text { Probably/not } \\
(n=7)\end{array}$ \\
\hline Treatment (use prophylactic, herbs) & 39 & 57 \\
$\begin{array}{l}\text { Improve on management practices } \\
\text { husbandry }\end{array}$ & 22 & 0 \\
$\begin{array}{l}\text { Feeding (use crop residues) } \\
\text { Hire more land for extensive grazing/ }\end{array}$ & 13 & 43 \\
$\quad$ fodder production & 9 & 0 \\
Use family labor/use causal labor & 9 & 29 \\
Seek expert advise & 4 & 14 \\
Advocacy for organic farming & 4 & 0 \\
Acquire loans & 4 & 0 \\
\hline
\end{tabular}


Fig. 3 Rating of factors that affect uptake of organic livestock production. Farmers were required to rate each of the 6 options as unimportant, important, or very important. y indicates responses from farmers willing to convert to organic dairy production and I from those not willing to convert

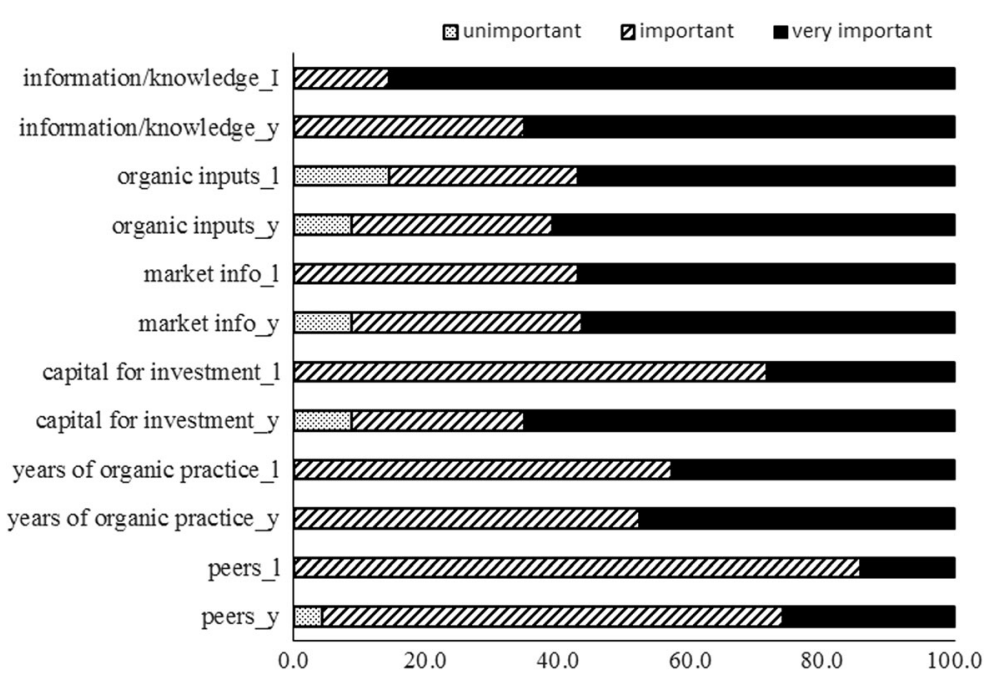

that education of farmers increases their ability to participate and to utilize market information and market opportunities (Umoh 2006; Lukas and Cahn 2008; Lubungu et al. 2012). Although organic livestock production practices, innovations, and technology may be relatively unknown in this study, the farmers know about the principles of organic farming since the arable/vegetable part of the farms was already converted. According to Sipiläinen and Oude Lansink (2005), experience gained over time and learning by doing may be important determinant in the efficiency of organic farming. Moreover, Bandura's Social Learning Theory posits that people learn from one another via observation, imitation, and modeling (Bandura 1977). Thus, people can learn from one another even under limitation of education provided social networks support them. Nevertheless, in the study area, there was no organic dairy farmer available to learn from, probably that is why the farmers also perceived peers as least important in uptake of organic dairy production. Therefore, initially, there will be a need for farmers' training in organic dairy production. The early adopters would then assist others to learn since organic farming knowledge system is a result of a vivid social learning process (Kummer et al. 2010).

Until now, farmers sell small amounts of milk on the local market without preferential demand for organic milk and no prospect for a premium price. Farmers' training must be accompanied by milk collection and marketing at premium price in urban areas to make conversion to organic dairy production profitable. This, therefore, calls for not only training certified organic pineapple farmers to learn how to integrate dairy cattle into their pineapple production with the added advantage of recycling cattle manure to the gardens as soil amendments while turning crop by-products into feeds, but also deliberating awareness creation among urban organic markets about the potential availability of dairy products. The availability of a more lucrative organic urban market for dairy products should then be able to drive the conversion of farmers to certified organic dairy producers similar to how lucrative export market to Europe influenced adoption of organic pineapple production.

Most of the surveyed farms had diversity of crops and livestock. This gives opportunity for interaction to enhance useful processes like soil building and nitrogen fixation, crop rotation plus nutrient recycling (Shennan 2008; Foissy et al. 2013). Due to the small land sizes owned, farmers venturing into pineapple production as a business were compelled to lease land elsewhere to cultivate organic pineapples. Such land is also inspected and certified as organic as the rest of the land farmers own. In the case of the organic pineapple fields at a distance from the homesteads where the livestock are kept, farmers have to make choices of whether or not to recycle nutrients between the farmed animals and organic pineapples. The number of animals and the eventual manure collected in relation to the land size for crop production is relatively low. The question is whether nutrients leaving the farm by selling crops and milk can be compensated for by animal manure from "cut and carry" feed from elsewhere. 
Farm diversity involving crops and livestock enabled nutrient recycling on almost all study farms. In a tethering system, a substantial part of fecal manure was deposited in the grazed fields. This action maintains the soil fertility of the grazed fields but makes the manure unavailable for use on the rest of the farm. Thus, only manure deposited overnight in kraals is accessible for use elsewhere. Farmers then have to make a decision on where to use the manure, whether in organic pineapple production or other crops, considering the distance of the pineapple fields from the homesteads where animals are kept and the value of the extra yield they get as revenue when the crops are provided the extra nutrients. This study showed that majority of the farmers opted to use manure in crops fields close to homesteads $(<$ $0.5 \mathrm{~km}$ ) other than pineapples fields far from homesteads.

Besides that, the number of livestock to land size ratio was low, thus small amounts of manure was available. Therefore, there will always be a shortage of manure for optimal soil conservation and crop production on the study farms. To ensure availability of all produced quantities of manure might imply confinement of cattle thereby limiting their free-grazing environment and outdoor movement, yet the organic principles and standards recommend that animals should be subjected to their natural behavior (EAOPS 2007). So, zero grazing systems, where cows are managed intensively while confined in stalls but also provided an exercise yard, could make manure collection easier; however, based on previous study, such zero grazing units in the study area required improvement in their hygiene and maintenance (Nalubwama et al. 2016). Such modified dairy housing system would enhance integration of some freedom of free animal movements in the exercise yard as well as ability to access and utilize all the manure efficiently. To maintain soil fertility on the entire area of the farm, the minerals leaving the farm with the marketed produces should be compensated for by promoting inputs such as organic soil amendments, foliar fertilizers, and biorationals.

The prospect of further benefiting from organic markets by producing organic dairy products like certified organic milk was the main motivation of one third of the farmers to convert to organic dairy production. In a recent study on organic consumer patterns in Uganda, it was reported that urban consumers bought organic products for perceived benefits like health, quality, environment, and animal welfare concerns (Anecho
2015). However, it was also reported that low consumption of organic animal products resulted from low availability in the urban markets. Majority of the milk does not reach the formal milk market and is used in the household and the surplus sold locally. But, despite the prospects of market for organic animal products in urban areas, livestock farmers in organic farming systems in Uganda today have not received enough incentive to spark off uptake of organic principles and standards unlike crops production (Nalubwama et al. 2011; Kiggundu et al. 2014).

This study identified various challenges farmers encounter in dairy cattle production which probably also limit their ability to venture into production of organic animal products. Animal pests and diseases were the major perceived problems highlighted by these smallholder farmers. The treatment and control of parasites and animal diseases in the tropics mainly rely on routine application of chemical anti-parasitic agents and drugs, respectively (Vaarst et al. 2006; Moyo and Masika 2009). So restrictions on the use of these agents in organic systems will require devising alternative strategies for disease prevention and control in cases where future conversion to organic dairy production is intended. Nonetheless, resource-constrained smallholder farmers in the tropics traditionally use few external inputs like synthetic drugs and antibiotics, keep adapted indigenous livestock breeds, and follow grazing based on extensive or semi-intensive production (Chander et al. 2011) implying that the road to transition to certified dairy production would be much easier. At the same time, in extensive production systems with small numbers of low-yielding cows, the incentives to convert to organic dairy production are small due to the limited amount of milk available for sale.

In addition, farming is dependent on rain; so during dry seasons, yields were poor due to limited natural pastures and thus low animal production. Probably that is why farmers mentioned scarcity of feeds during dry season as a major challenge. Amidst this challenge, only few farmers provided supplementary feeds like crop residues as a coping strategy. None of the farmers mentioned storage of hay or silage harvested during the rainy season to be used in the dry season. This could mean that farmers focus their efforts on pineapple and other crop production and do not spend efforts on dairy cows. Without putting efforts in adequate feeding the whole year round, the number of dairy cows and the milk yield per cow will be low, and the smallholder farmers will 
continue to produce for subsistence mainly. In this study, the possibility of marketing organic animal products was a motivation expressed by the farmers for their willingness to convert to organic dairy production. There is a discrepancy between farmers' willingness to convert and the actual conversion: none of the farmers converted to organic dairy, probably because of imbalance between the efforts it requires to have quality dairy husbandry and the incentives for organic dairy production. The willingness of certified organic pineapple farmers to convert to organic dairy cattle production should not only be driven by the availability of lucrative organic urban market but also by the advantages of cattle manure to the gardens as soil amendments and by the availability of crop by-products as cattle feeds. However, deliberate awareness creation on organic animal husbandry, access to organic input, and organized organic markets will play a crucial role as incentives for conversion to organic dairy production.

\section{Conclusion}

Integrating dairy cattle with pineapple production was perceived by farmers as an opportunity for closing nutrient cycles in terms of feeding animals with byproducts from the crop production, and fertilizing land with cattle manure, as well as income diversification. The distance between animals and pineapple fields was a major challenge for their integration, and farmers were generally unwilling to carry manure and feed more than $500 \mathrm{~m}$. Other challenges were animal diseases and dry season feed scarcity. Farmers perceived weather variability, lack of knowledge, and limited markets for milk as major risks for dairy production on their farms. While majority of organic pineapple farmers expressed willingness to covert to organic dairy production, there is a need to overcome the challenges and risks perceived presently in dairy production to make the efforts and investment worthwhile doing. Therefore, to enhance crop-livestock integration in organic systems, there is a need for provision of knowledge to farmers on organic animal husbandry, access to organic inputs, and organized markets.

Funding information The study received support from the Danish Agency for International Development (DANIDA) for sponsoring the research through the Productivity and Growth in Organic Value Chains (ProGrOV) project.

\section{Compliance with ethical standards}

Statement of animal rights The manuscript does not contain clinical data studies or patient.

Conflict of interest The authors confirm that they have no conflict of interest.

\section{References}

Anecho S (2015) Understanding organic consumer characteristics in the metropolis of Kampala, Uganda. Msc Dissertation, Makerere University, Kampala, Uganda

Bandura A (1977) Social learning theory. General Learning Press, New York

Chander M, Subrahmanyeswari B, Mukherjee R, Kumar S (2011) Organic livestock production: an emerging opportunity with new challenges for producers in tropical countries. Rev Sci Tech Off Int Epiz 30:969-983

Chongtham IR, Neegaard AD, Pilot D (2010) Assessment of the strategies of organic fruit production and fruit dying in Uganda. J Agric Rural Dev Trop Subtrop 111:23-34

EAOPS (2007) East Africa Organic Product Standards. EAS 456: 2007 http://www.oecd.org/aidfortrade/47719232.pdf. Accessed 4 Dec 2015

FIT (2007) Study for fruits sub-sector (pineapples, passion fruits, mangoes), final report by FIT Uganda. http://www.fituganda. $\mathrm{com} / \mathrm{manage} /$ download/atm/marketreports/subsectorstudyfruits. pdf. Accessed 4 Oct 2016

Foissy D, Francois-Vian J, David C (2013) Managing nutrient in organic farming systems: reliance on livestock production for nutrient management of arable farmland. J Org Agric 3:183199. https://doi.org/10.1007/s13165-014-0060-8

ICROFS (2010) International Centre for Research in Organic Food Systems how organic agriculture contributes to economic development in Africa: market driven development of organic high value chains. ICROFS facts sheet Number 4 (2010). http://icrofs.dk/fileadmin/icrofs/Nyheder PDf/Faktaark_nr_4.pdf. Accessed 11 Dec 2016

IFAD (2005) International Federation of Agricultural Development. Integrated crop-livestock farming systems. Livestock thematic papers. http://ifad.org/lrkm/index.htm. Accessed 11 Dec 2016

Karki L, Schleenbecker R, Hamm U (2012) Factors influencing a conversion to organic farming in Nepalese tea farms. J Agric Rural Dev Trop Subtrop 112:113-123

Kavoi J, Mwangi J, Kamau G (2013) Strategies for effective multi stakeholder linkages for innovative agricultural development in semiarid areas of eastern Kenya. US-China J Public Adm 10:497-506

Kiggundu M (2015) Potential of ensiling organic pineapple byproducts as dairy cattle feed on organic certified farms. Msc. Thesis, Makerere University, Kampala, Uganda

Kiggundu M, Kabi F, Vaarst M, Nalubwama S, Odhong C (2014) Management and use of dairy cattle feed resources on 
smallholder certified organic pineapple farms in Central Uganda. J Agric Environ Int Dev 108:207-225

Kummer S, Aigelsperger L, Milestad R, Chowdhury AH, Vogl CR (2010) Knowledge system, innovations and social learning in organic farming-an overview. 9th European IFSA Symposium, 4-7 July 2010, Vienna (Austria)

Kwikiriza N, Rye MJ, Kledal P, Karantininis K, Namuwooza C (2016) Tracing Uganda's global primary organic pineapple value chain. Afr Crop Sci J 24:15-33

Lubungu M, Chapoto A, Tembo G (2012) Smallholder farmers participation in livestock markets: the case of Zambian farmers. 66, Indaba Agricultural Policy Research Institute (IAPRI) Middleway, Kabulonga, Lusaka, Zambia

Lukas M, Cahn M (2008) Organic agriculture and rural livelihoods in Karnataka, India. Paper presented at the IFOAM Organic World Congress, Modena, Italy

Martine-Garcia CG, Ugoretz SJ, Arriaga-Jordan CM, Wattiaux MA (2015) Farm, household and farmer characteristics associated with changes in management practices and technology adoption among dairy smallholders. Trop Anim Health Prod 47:311-316. https://doi.org/10.1007/s11250-014-0720-4

McDermott JJ, Sere C, Rosegrant M (2010) Smart investments in sustainable food production: revisiting mixed crop-livestock systems. Science 327(5967):822-825

Moll HAJ, Staal SJ, Ibrahim MNM (2007) Smallholder dairy production and markets: a comparison of production systems in Zambia, Kenya and Sri Lanka. Agric Syst 94:593-603

Moyo B, Masika PJ (2009) Tick control methods used by resource-limited farmers and effect of ticks on cattle in rural areas of the Eastern Cape Province, South Africa. Trop Anim Health Prod 41:517-523. https://doi.org/10.1007/s11250008-9216

Nalubwama SM, Mugisha A, Vaarst M (2011) Organic livestock production in Uganda: potentials, challenges and prospects. Trop Anim Health Prod 43:749-757
Nalubwama S, Vaarst M, Kabi F, Kiggundu M, Bagamba F, Odhong C, Mugisha A, Halberg N (2014) Challenges and prospects of integrating livestock into smallholder organic pineapple production in Uganda. Livest Res Rural Dev 26

Nalubwama S, Vaarst M, Kabi F, Smolders G, Kiggundu M (2016) Cattle management practices and milk production on mixed smallholder organic pineapple farms in Central Uganda. Trop Anim Health Prod 48(8):1525-1532. https://doi.org/10.1007 /s11250-016-1123-5

Negesse T, Makka HPS, Becker K (2009) Nutritive value of some non-conventional feed resources of Ethiopia determined by chemical analyses and an in vitro gas method. Anim Feed Sci Technol 154:204-217

Pauselli M (2009) Organic livestock production as a model of sustainability development. Ital J Anim Sci 8(Suppl.2):581587

Shennan C (2008) Biotic interactions, ecological knowledge and agriculture. Philos Trans R Soc B-Biol Sci 363(1492):717739. https://doi.org/10.1098/rstb.2007.2180

Sipiläinen T and Oude Lansink A (2005) Learning in organic farming - an application on Finnish dairy farms. European Association for Agricultural Economist Congress. Copenhagen, Denmark, August 24-27

Umoh GS (2006) Resource use efficiency in urban farming: an application of stochastic frontier production function. Int $\mathrm{J}$ Agric Biol 8:38-44

Vaarst M, Roderick S, Byarugaba DK, Kobayashi S, RubaireAkiiki C, Karreman HJ (2006) Sustainable veterinary medical practices in organic farming: a global perspective. In: Halberg N, Alrøe HF, Knudsen MT, Kristensen ES (eds) Global development of organic agriculture, challenges and prospects. CABI Publishing, Wallingford, pp 241-276

Willer H, Lernoud J (2015) The world of organic agriculturestatistics and emerging trends 2015. FiBL-IFOAM Report. Research Institute of Organic Agriculture (FiBL), Frick, and IFOAM-Organics International, Bonn, p. 306 